\title{
THE CHARACTERISTICS OF VILLAGE COMMUNITIES IN THE DISASTER RESPONSE AREA (A CASE STUDY OF CIJERUK VILLAGE, WEST JAVA)
}

\author{
Syamsul Maarif ${ }^{1}$, Deffi Ayu Puspito Sari ${ }^{2 *}$ \\ ${ }^{1}$ Indonesia Defense University, Indonesia, ${ }^{2}$ Universitas Bakrie, Indonesia. \\ Email: ${ }^{1}$ maarif.syamsu173@gmail.com, ${ }^{2 *}$ deffiayu@ gmail.com
}

Article History: Received on $30^{\text {th }}$ September 2019, Revised on $30^{\text {th }}$ December 2019, Published on $01^{\text {st }}$ February 2020

\begin{abstract}
Purpose of the study: The purpose of this study is to present a description and analysis related to the characteristics of the people exposed to disaster-prone areas, in villages (rural) and kelurahan (urban) levels, public awareness of efforts to "maintain" their survival from external disturbances, conformity to program interventions/activities carried out by external parties (government / non-government).
\end{abstract}

Methodology: In principle, this study uses an approach based on qualitative research.

Main Findings: From the results of the research obtained based on the experience of the residents, two of the largest outflows of capital were obtained, namely social capital and human capital, while the least capital outflows were natural capital.

Applications of this study: This research will be carried out in the rural area with the threat of landslides in Cijeruk Village, Bogor Regency.

Novelty/Originality of this study: Sustainable Livelihood Assessment (SLA), the higher the frequency of the key behavior of the components of capital out of the SLA, the more capital is needed by a community. From the results of the research obtained based on the experience of the residents, two of the largest outflows of capital were obtained, namely social capital and human capital, while the least capital outflows were natural capital.

Keywords: Suistanable Livelihood Assessment (SLA), Human Capital, Social Capital, Natural Capital, Physical Capital, Financial Capital.

\section{INTRODUCTION}

The Aceh tsunami disaster has become a wake-up call for the world. Disasters have a detrimental impact, threatening the safety of human life, disrupt the community and affect national stability (Mamnunia, Sari, \& ..., 2018). Such a large number of victims have made the world aware of the meaning of disaster risk reduction. Risks as potential losses that can be death, life threats, material losses, and disruption of socio-economic activities of communities caused by disasters (D. A.P. Sari, Innaqa, \& Safrilah, 2017).

As a country located in the Pacific Ring of Fire and surrounded by three tectonic plates causes Indonesia as a disasterprone area, therefore, the efforts to reduce disaster risk continue to be done (Wati, Sari, \& Sutisna, 2018). Indonesia, since the disaster incident swiftly immediately made law on Disaster Management. This is based on awareness of the threats that at times become disasters and disrupt the lives of people (Carley, Malik, Landwehr, Pfeffer, \& Kowalchuck, 2016; Carley et al., 2016; Chatfield \& Brajawidagda, 2013; Kusumasari \& Alam, 2012; Marfai \& King, 2008; Morgan et al., 2006).

From the defense aspect, disasters are non-military threats that can weaken the supporting components of defense (Deffi Ayu Puspito Sari, Malahayati, Nefianto, \& Kertawidana, 2018). In-Law No. 3 of 2002 concerning National Defense, it is explained that the intended supporting component is national resources that can be used to increase the strength and capability of the main components and reserve components (Republik Indonesia, 2002). This means that the non-military threat (disaster) must be faced through a series of non-military efforts. The professionals get the task as the main element to overcome this threat. Knowledge management is very important for human resource management, one of them related to the development of multipurpose technology for the present the best service quality (Fajarianto, Setiawan, Mursidi, Sundiman, \& Sari, 2011).

In some disaster events, most of these capacities tend to decrease and even disappear. The capacity reduction also allows disasters to tend to be present repeatedly in an area and community (Allen, 2006; Loayza, Olaberria, Rigolini, \& Christiaensen, 2012). According to the concept of sustainable livelihood, there are five livelihood assets owned by each individual or social unit that are higher in their efforts to sustain life (Ali, Ahmad, Shahbaz, \& Suleri, 2007; Chen et al., 2013; Faiz, Faiz, Wang, \& Bennett, 2012; Parkinson \& Ramirez, 2006), namely: (1) human capital, namely capital owned by humans; (2) social capital, is the social capital owned by the community; (3) natural capital, is the supply of natural resources; (4) physical capital, is the basic infrastructure and produces goods needed; and (5) financial capital, namely financial resources used by the community to achieve their life goals. Every individual, community and larger social unit develops this capacity in responding to threats. The response is short-term, called a coping mechanism or a 
long-term mechanism known as an adaptation mechanism. The mechanism in dealing with changes in the short term primarily aims to access basic life needs: security, clothing, food. While for the long term it aims to strengthen the sources of life. When disasters occur, basic needs become very complex problems, especially those related to access and availability. Frequently attacked by disasters is one of the triggers of food insecurity (Puspito Sari, Listiyowati, Nefianto, \& Lasmono, 2018). The disaster victims often have to wait long enough because they have to wait for the distribution supplied from outside. Such conditions ultimately lead to a social vulnerability that has the opportunity to lead to vertical and horizontal conflicts (Lindell \& Prater, 2003; Nel \& Righarts, 2008; Olshansky, Hopkins, \& Johnson, 2012).

Recently the concept of disaster management has undergone a fairly fundamental change. The meaning of a disaster that is conventionally considered an event that cannot be prevented has undergone a shift. Disasters are believed to be predictable so prevention and risk reduction efforts can be carried out. The timeframe and focus of assistance that was initially only oriented towards providing physical, technical assistance and only carried out during disaster response, has changed to the concept of community-based disaster management, through disaster management works carried out before the disaster occurred, namely through prevention efforts risk reduction and early warning. Assistance is also more comprehensive including trauma or psychosocial assistance.

A very fundamental change is seen in the role of stakeholders in disaster management. As mandated in Law 24/2007, that disaster management activities must involve three pillars, namely the government, the private sector or the business world and the community itself (the Republic of Indonesia, 2007). In line with this, in view of CBDM (Community Based Disaster Management), disaster management is the responsibility or involves everyone's participation, even though the main person in charge remains with the government. The implementation of community pillar participation is very emphasized because the people affected by the disaster are those who have the experience, face to face, and who experience the consequences the most, of course, they understand the needs and ways to overcome them.

From a defense perspective, it is expected that the community can deal with any threat that comes. Natural threats in the form of floods and landslides that are a type of hydrometeorological threat should have been known to the public for years. For this reason, it is necessary to map the extent to which the community in one area has the capacity according to the sustainable livelihood concept mentioned above. Natural threats in the form of floods and landslides can be considered as "enemies" which at certain times will "attack" the people who live around vulnerable areas. Communities need to be organized so that they have preparation when the rainy season comes. Communities must be prepared to face floods, flash floods, and landslides, to reduce disaster risk. That is the model of the defense system that needs to be realized so that the community from the beginning has strengthened its social organization to face external threats (natural threats). The coordination that is realized from various components, both the community, the civil government, the business world, and the military, must be increased so that disaster management capacity based on the village / kelurahan can be realized. What needs to be considered later is how social maps in the form of community characteristics in rural areas and rural communities organized can be identified and explained.

\section{RESEARCH PURPOSES}

The purpose of this study is to present a description and analysis related to, (i) the characteristics of the people exposed or affected people in disaster-prone areas, in villages (rural) and kelurahan (urban); (ii) public awareness of efforts to "maintain" the continuity of their lives from external disturbances; (iii) conformity of program/activity interventions carried out by external parties (government / non-government) with the characteristics of the community as well as efforts that have been made by the community itself; and (iv) formulation of program and activity recommendations and the required assessment format.

\section{METHOD}

In principle, this study uses an approach based on qualitative research. This research will be carried out in two prone areas with rural characteristics. For the rural area with the threat of landslides in Cijeruk Village, Bogor Regency. Furthermore, the determination of the sample in this study uses purposive sampling or often also termed interactional or theoretical sampling, and is not a representative sampling.

This measuring instrument uses an open type of question, which will then be assessed in content analysis. The researcher will determine family resilience and key behavior based on the quality of answers from the respondents. Each answer that corresponds to the behavior of the key will be given a value of 1 . The results will be accumulated in accordance with the category of factors of sustainable livelihood assessment (SLA). Variations in respondents' answers will be grouped into several categories based on the 5 components of sustainable livelihood capital.

\section{DISCUSSION}

\section{Interview result}

\section{General Picture of Tajur Halang Village Area}

According to an explanation from Mr. RW, Tajur Halang Village is one of the villages where the majority of the population comes from the same descendants, they are large families who have lived in the area downhill and are now 
mingling with outsiders. From this explanation, it can be seen how closely the kinship between each other, it is so close that communication and mutual help develop well in this region.

Most of the population in this village have a livelihood as dairy farmers, farmers and traders. The location where they work is on a hillside close to their home. The habit of people in developing agriculture/plantations does not pay attention to the slope, opening new lands on the slopes of the hills causes the surface of the slopes to open without the proper arrangement of the water system (drainage system), and the forms of bench terraces on the slopes need to be done brake the rate of erosion.

Their farms/plantations are located in the hills so that many hills do not have cambium trees that have strong roots to hold the soil on each slope. But they mitigate through making waterways around their plantations and making terraces or steps as their land for gardening.

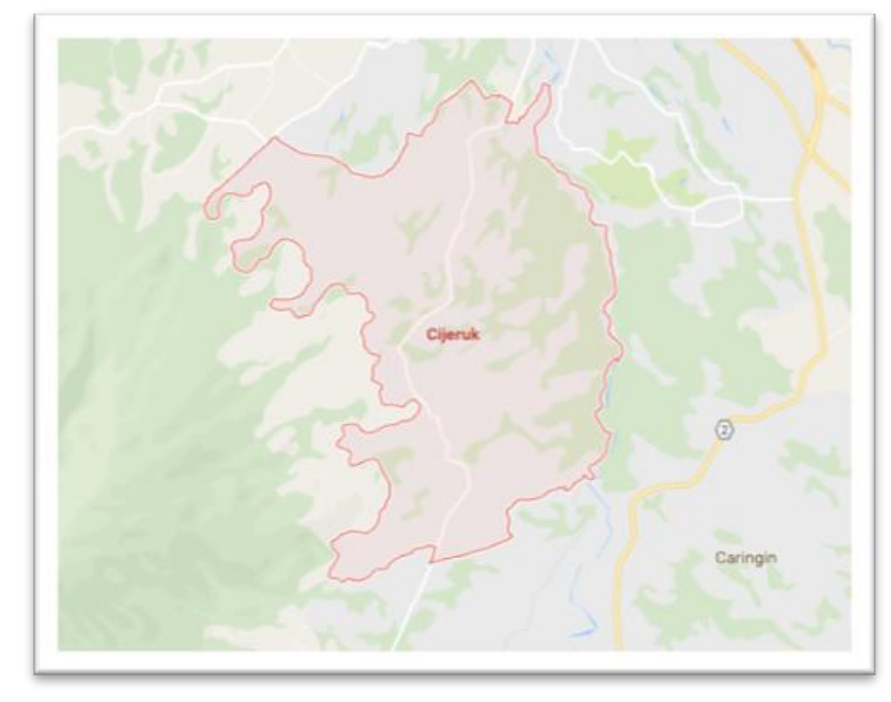

Figure 1: Map of Administrative Village of Tajur Halang, Cijeruk, Bogor

Source: (Google Map)

\section{Condition of Tajur Halang Village}

The staff of the Tajur Halang village government revealed that the Tajur Halang Village area is the area that has the highest altitude in the Cijeruk area. Tajur halang is also a densely populated area that is located right on the hillsides in the village of Tajur Halang, Cijeruk, Bogor. Population density causes the development of housing towards hilly areas (hill slopes) that are not in accordance with the land use (land use), causing a burden on the slope (surcharge) increasingly heavy. This village often experiences landslides, but according to the testimony of residents, the incident until now can still be tackled together and has not caused casualties. The residents also stated that there were other threats besides landslides that threatened them, namely the tornado disaster that occurred in 2013. According to information, the incident only happened once.

The last landslide disaster occurred in March 2016. This incident resulted in road access being covered by land avalanches, but the settlement was safe from landslides. In this incident, it was stated that no residents had been displaced but resulted in electricity outages in the settlement for several days.

Mr. RW and RT stated that in facing the consequences of the disaster, residents were the first parties to feel the consequences of the disaster. This causes residents or families to become vulnerable to disaster risk. Community groups at risk of disasters are seen from their age group and gender.

The following is the population data of the Tajur Halang Village in terms of their area and gender. Tajur Halang village based on Tajurhalang in the 2015 figure has a population of 17,320 consisting of 8,839 men and 8,481 women. The area of Tajur Halang Village is $6.12 \mathrm{KM} 2$ with a population density of 2830 people / KM2.

\section{The History of Landslides in Tajur Halang Village}

From the explanation of Mr. RW and RT, it is obtained the information that a landslide had become a common occurrence in the village of Tajur Halang. This event usually occurs when the intensity of rainfall is high and continues for several days. In this situation, usually, the RTs and RWs were on standby in the event of a landslide. The village government will usually inform you about the weather forecast obtained from the BMKG and inform the RWs and RTs, and the Linmas officers to be alerted via SMS. 
They also stated that the last landslide disaster occurred in March 2016. Resulting in public access to the city covered by landslides. This incident occurred in the afternoon, heavy rain continued for several days. After the incident, the RW and RT reported the matter to the village government. The Village Government immediately sent assistance in the form of heavy equipment to get rid of landslides from the road. This was done in cooperation with residents.

\section{The Characteristics of Landslides in Tajur Halang Village}

Soil movement is one of the geological processes that occur due to the interaction of several conditions including geomorphology, geological structure, hydrogeology, and land use. These conditions are mutually influential so that the slope conditions tend to move (Karnawati, 2011)

Soil movements can be identified through the following signs: the emergence of tensile cracks and wrinkles on the slope surface, broken pipes and electric poles, sloping trees, road pavements that are located on the heap have collapsed, damaged road equipment such as safety fences and drainage channels, the closure of expansion joints on the bridge plate, loss of alignment from the building foundation, cracked building walls, and cracking retaining walls and forward sloping (Hardiyatmo, 2012).

Land movement that occurs in the area of Tajur Halang Village is the movement of land with a type of landslide Avalanche (Slide) is a downward movement of the slope by the material making up the slope, through the slip plane on the slope. Often the earliest signs of movement are in the form of horseshoe cracks on the surface of the slope that begin to move. This slip-plane can be either a relatively straight field (translation) or an upward curved plane (rotation), as shown in Figure 2.

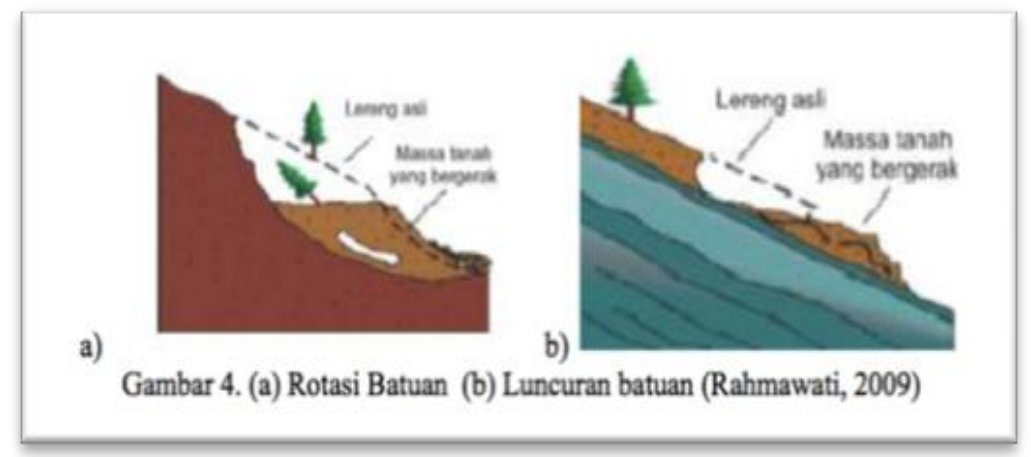

Figure 2: Land Movement

\section{Characteristics of Exposed Communities in the area of Tajur Halang Village}

The Sustainable Livelihoods Assessment (SLA) approach conducted by researchers in the Tajur Halang Area, Cijeruk, Bogor aims to identify five (5) capital in the face of landslides, namely human capital, social capital, natural capital, physical capital, and financial capital. This approach is based on the belief that the community must be able to independently detect threats or potential disasters that will arise or not always have to depend on external parties. The results obtained from interviews and FGDs on 10 residents living in Tajur Halang Village are as follows:

Table 1: Results of Interviews and FGDs

Capital Kndicators
Knowledge of Landslide Disaster Risk Reduction
- Attend disaster management training related to landslides
- involved in handling landslides
- had been a victim of a landslide
- know the signs before the landslide

Community Behavior

- Make efforts to protect the environment to avoid landslides

- Make efforts to maintain the environment around the slopes

- Conduct preventive activities regularly and continuously

- Conduct tree planting initiatives in areas that experience deforestation in the Tajur Halang area

\section{Human Capital}


- Knowing that the location of his residence in an area prone to landslides

- Make prevention efforts to avoid landslide hazards

- There are plans related to disaster management

- Have an understanding of landslide early warning

- There is learning after the experience of landslide events

Community preparedness

- There are activities carried out by the community together to reduce the risk of landslides

- There is training or outreach related to landslide management in the Tajur Halang area

- There are no community contingency plans in the face of landslides

- No place has been agreed upon by the community to be used as a refuge when landslides occur

Formal organizational structure patterns

- there are formal organizations in the area of the father/mother related to landslide disaster management (BPBD)

- Village officials are involved in PB organizations

- There have been no activities related to Disaster Management that have been carried out in the village of Tajur Halang

The pattern of informal organizational structure

- There is a disaster alert group in the Tajur Halang area

- There is the involvement of citizens in the disaster alert group

Social capital

(19)

- The organizational structure is under the village government

- There are no activities related to Disaster Management that have been carried out by disaster groups

- Karang Taruna has not been active and knows about disaster

The pattern of Relationships between citizens

- There are activities based on mutual cooperation that are routinely carried out

- The close kinship between residents in the village

- When there is a landslide the community selves to help one another

- Community members know each other well with each other

The process of communication between citizens and the government

- There are regular meetings between residents and the village government

- The government has conducted socialization related to disaster management

Government policy on Disaster Management (Special for village government)

- Village parties do not have a special budget to allocate in disaster management

- The village provides funding assistance during a landslide

- The village party does not have PB related documents such as RPB, Renkon, or PB Action Plan

- The village has formed a village volunteer/standby team

- Community involvement in the village volunteer/standby team

- $\quad$ BPBD has not been socialized in landslide areas

Natural Capital

(1)

\section{Environmental Resilience}

- There are no tall trees in the village that can prevent landslides

- There are terraces in the hillsides in the Tajur Halang area

\begin{tabular}{ll}
\hline $\begin{array}{l}\text { Physical capital } \\
\text { (7) }\end{array}$ & Structural mitigation; \\
& There are the formation of gabions or landslide retention buildings in \\
& landslide-prone areas \\
- There is no place for evacuation in the event of a landslide & There are already lines and evacuation signs \\
- There are already landslide early warning systems & \\
\hline
\end{tabular}


- $\quad$ There are residential areas in areas prone to landslides

Public and social facilities

- There are public facilities that can be used when landslides occur

- There are social facilities that can be used during a landslide disaster

Early recovery system

- There are already landslide early warning systems

- There is a communication network to inform disaster information to residents

Financial Capital

(2)
Community Work Activities

- Most of the residents are farmers, farmers, and traders

- The location of work is an area prone to landslides

- There has never been a landslide in the working location

- There are no other alternative livelihoods if landslides hit the workplace 2

Disaster Savings Fund

- There are no savings/deposits in preparation for landslides

- There has been no fundraising done by the community

- Use of village funds for emergencies

Total toughness

From the results of the research obtained based on the experience of the residents, two of the largest outflows of capital were obtained, namely social capital and human capital, while the least capital outflows were natural capital.

\section{Perception of the Risk of Residents in the Tajur Halang Area}

Citizens' perceptions of a threat will be different when the residents continue to face the same disaster, their perceptions of the disaster will also change. This happened in the village of Tajur Halang, the residents who had experienced more than two landslides had other views regarding landslides. The residents have a habit of measuring when landslides will occur by seeing the intensity of high rainfall falling in succession for more than two days as their reference. When the residents were asked about their opinions about landslides, they said that the landslide was not a major disaster for them. A tornado is a disaster that is considered by residents of Tajur Halang Village as a major disaster because the damage caused is very severe compared to landslides. This risk perception makes them quite alert to the threat of landslides that will follow if rainfall does not stop for more or less for two consecutive days.

To find out the perceptions of the residents regarding landslides the researchers conducted FGDs on the landslide category by using the length of rainfall that fell and the location of the landslide. Based on the results of discussions with the residents, the following results arise:

1. Normal: If rainfall occurs less than two days with moderate intensity.

2. Disruptive but still manageable: If rainfall occurs for 2 days with moderate intensity.

3. Insurmountable: If rainfall occurs more than 2 days with high intensity continuously.

4. Major disasters: If rainfall occurs more than 5 days with high intensity continuously.

5. Fatal: If rainfall occurs more than 7 days with high intensity continuously.

Based on the residents' risk perceptions above, it can be concluded that perceptions of the risk of residents going to landslides with rainfall occurring for 2 (two) days with moderate intensity disturbing but can be overcome. In this case, the residents realized that in more than 2 days such intervals could disrupt their activities but they could still deal with it in mutual cooperation without waiting for help from the government and carrying out independent evacuations to safer places by avoiding the cliff slopes that were not yet plaster. This is enough to show that residents in Tajur Halang Village have a good perception of the threat of landslides because they do not underestimate rainfall and its intensity by gathering information to always be alert in the face of landslides.

\section{CONCLUSIONS}

Based on the results and data analysis of research conducted on residents living in RW 02, 05 and 08 in areas prone to landslides, Tajur Halang Village, Tajur Halang District, Cijeruk, Bogor Regency, it can be summarized as follows:

1. Based on the data obtained, the general picture of sustainable livelihood assessment (SLA) is obtained according to John Twigg, namely human capital, social capital, natural capital, physical capital, and financial capital. So it can be 
concluded that the capital components of the theory of sustainable livelihood assessment (SLA) can still explain the phenomenon of the capacity of communities living in areas prone to landslides, in Tajur Halang Village, Tajur Halang District, Cijeruk, Bogor Regency.

2. Based on the data obtained, the higher the frequency of the capital component of sustainable livelihood assessment (SLA) means that it has a more significant influence on the capacity of the community itself. This capital model is very necessary for increasing the capacity of DRRB in areas prone to landslides, Tajur Halang Village, Tajur Halang District, Cijeruk, Bogor Regency. There are 2 capital components of sustainable livelihood assessment (SLA) that have the highest frequency of occurrence. The 2 capital components are human capital and social capital. While the natural capital component is the lowest compared to the others. However, in addition to the 2 capital components of sustainable livelihood assessment (SLA) above, the other components are physical capital and financial capital; it also needed to help citizens overcome the impact of landslides that are fully experienced and help residents to have resilience.

3. Residents in Tajur Halang Village have 5 components of capital that are quite good because they find behaviors from residents such as fathers, mothers, and youth who support the capacity of disaster-based communities. This can be seen from the active role of the fathers, the mothers and youths of Karang Taruna who work together in mutual service activities such as making drains on the slopes of the cliffs as rainwater channels, slope rock slope using stones and cement, and also work together in conducting cleaning in the event of a landslide.

4. The residents in Tajur Halang Village have a fairly good risk perception about the risk of landslides and knowledge to deal with landslides if they occur. The community has understood that the intensity of rainfall is a trigger for landslides in their area. They are now aware of the rainfall and its intensity. Citizen awareness increases over time gradually. This was due to residents being vigilant despite frequent landslides.

5. From the community capacity analysis, it was found that the community in Tajur Halang had a good early warning system with the existence of a communication network and village officials who were actively and effectively delivering the news via SMS to the families.

6. Based on the research, it can be concluded that the Tajur Halang community is a fairly resilient society. The community has tried to reduce vulnerability and increase its physical and human capacity. The Tajur Halang community has been able to anticipate all forms of threats, in this case, the threat of landslides; the community that is able to protect/fight or avoid threats; people who are able to adapt quite well and can adjust to the conditions that are happening. The community has shown high self-awareness because they have participated in planning Disaster Risk Reduction activities in the area where they live.

7. Tajur Halang Village needs to get outside intervention in an effort to increase capacity both physically and human resources. These external interventions can be carried out by the government, in this case, the Bogor Regency BPBD, academics such as universities and disaster centers such as Unhan PSB, IPB, Scouts, and NGOs or other NGOs like PKPU, MDMC. Tajur Halang village can be a built village to become a resilient village of disasters.

8. The limitation of this study is that there is a cultural bias because the theory used is a theory originating from the western region and there is a sample bias because it does not involve the public more evenly and the government as the policyholder.

\section{SUGGESTIONS}

Based on the above conclusions, it is suggested:

1. For residents who live in Tajur Halang, filtered data can be used as input to improve community resilience when a landslide comes. Communities need to increase natural capital such as planting water retaining trees, making terraces on each slope to be planted with plantation crops; physical capital such as thickening of concrete on the hillside accompanied by water channels on each cliff patched with cement; financial capital such as disaster savings that are collected independently by citizens.

2. For residents who live in Tajur Halang, it is recommended that they still be able to remain in their area now but must also be accompanied by an increase in the component of community resilience such as alternative economic sources that still need to be improved for their survival when the landslide comes.

3. For the youth who live in Tajur Halang Village, counseling and education can be provided on first aid or emergency response processes in the event of a landslide disaster. This can work with the BPBD Bogor Regency.

4. For the Bogor Regency government to conduct a review and pay attention to the community in the Tajur Halang area so that they can help improve the resilience of the community in terms of physical resilience that is like completing the equipment needed when evacuating when landslides come.

5. It is recommended for village heads, RWs and RTs to work together in directing and improving the quality of community resilience in overcoming landslide problems. 
6. It is recommended to conduct further research on further evaluating the results of research to see the effectiveness of community resilience in landslide-prone areas other than the Tajur Halang village area so that it can be used as a basis for the process of increasing PRRBK capacity in areas prone to landslides in West Java.

7. This research can be used to use the highest weight by looking at the frequency. Virtue can only be obtained based on the number of capital components in sustainable livelihood assessment (SLA) that appear (based on frequency). However, this study has not found a norm that can determine the main and supporting division of capital components.

This study uses theories developed from western society, therefore the recommendations need to be formulated or carried out a sustainable livelihood assessment approach based on values in non-western communities.

\section{LIMITATION AND STUDY FORWARD}

This research is limited to one case that occurred in CijerukVillage, Bogor Regency. The results of this study can be beneficial for activists and stakeholders. Further research is needed on the threat of landslides.

\section{IMPLICATION}

Further research is needed in cases that are in accordance with future technological developments. This research will contribute to the knowledge of the threat of landslides.

\section{ACKNOWLEDGMENT}

We would like to show our gratitude to Indonesia Defense University, and to the Universitas Bakrie, and to the independent reviewers of HSSR who conducted a feasibility study of our research work.

\section{REFERENCES}

1. Ali, T., Ahmad, M., Shahbaz, B., \& Suleri, A. (2007). Impact of participatory forest management on vulnerability and livelihood assets of forest-dependent communities in northern Pakistan. The International Journal of Sustainable Development \& World Ecology, 14(2), 211-223. https://doi.org/10.1080/13504500709469721

2. Allen, K. M. (2006). Community-based disaster preparedness and climate adaptation: local capacity-building in the Philippines. Disasters, 30(1), 81-101. https://doi.org/10.1111/j.1467-9523.2006.00308.x

3. Carley, K. M., Malik, M., Landwehr, P. M., Pfeffer, J., \& Kowalchuck, M. (2016). Crowdsourcing disaster management: The complex nature of Twitter usage in Padang Indonesia. Safety Science, 90, 48-61. https://doi.org/10.1016/j.ssci.2016.04.002

4. Chatfield, A. T., \& Brajawidagda, U. (2013). Twitter early tsunami warning system: A case study in Indonesia's natural disaster management. 2013 46th Hawaii International Conference on System Sciences, 2050-2060. IEEE. https://doi.org/10.1109/HICSS.2013.579

5. Chen, H., Zhu, T., Krott, M., Calvo, J. F., Ganesh, S. P., \& Makoto, I. (2013). Measurement and evaluation of livelihood assets in sustainable forest commons governance. Land Use Policy, 30(1), 908-914. https://doi.org/10.1016/j.landusepol.2012.06.009

6. Faiz, A., Faiz, A., Wang, W., \& Bennett, C. (2012). Sustainable rural roads for livelihoods and livability. Procedia-Social and Behavioral Sciences, 53, 1-8. https://doi.org/10.1016/j.sbspro.2012.09.854

7. Fajarianto, O., Setiawan, M. I., Mursidi, A., Sundiman, D., \& Sari, D. A. P. (2011). The Development of Learning Materials for Introduction of Animals in Early Childhood Using Augmented Reality. 2011 5th International Conference on Application of Information and Communication Technologies, AICT 201 1, 1, 722 727. https://doi.org/10.1109/ICAICT.2011.6110900

8. Hardiyatmo, H. C. (2012). Tanah longsor dan Erosi: Kejadian dan Penanganan. Gadjah Mada University Press

9. Karnawati, D., Fathani, T. F., Ignatius, S., Andayani, B., Legono, D., \& Burton, P. W. (2011). Landslide hazard and community-based risk reduction effort in Karanganyar and the surrounding area, Central Java, Indonesia. Journal of Mountain Science, 8(2), 149-153. https://doi.org/10.1007/s11629-011-2107-6

10. Kusumasari, B., \& Alam, Q. (2012). Bridging the gaps: the role of local government capability and the management of a natural disaster in Bantul, Indonesia. Natural Hazards, 60(2), 761-779. https://doi.org/10.1007/s11069-011-0016-1

11. Lindell, M. K., \& Prater, C. S. (2003). Assessing community impacts of natural disasters. Natural Hazards Review, 4(4), 176-185. https://doi.org/10.1061/(ASCE)1527-6988(2003)4:4(176)

12. Loayza, N. V, Olaberria, E., Rigolini, J., \& Christiaensen, L. (2012). Natural disasters and growth: Going beyond the averages. World Development, 40(7), 1317-1336. https://doi.org/10.1016/j.worlddev.2012.03.002

13. Mamnunia, N., Sari, D. A. P., \& ... (2018). The Influence of Leadership and Competence in Puskesmas Preparedness for Supporting Flood Disaster Management (Case Study of Samarinda City in East .... ... and Disaster Management, 18-26.

14. Marfai, M. A., \& King, L. (2008). Coastal flood management in Semarang, Indonesia. Environmental Geology, 55(7), 1507-1518. https://doi.org/10.1007/s00254-007-1101-3 
15. Morgan, O. W., Sribanditmongkol, P., Perera, C., Sulasmi, Y., Van Alphen, D., \& Sondorp, E. (2006). Mass fatality management following the South Asian tsunami disaster: case studies in Thailand, Indonesia, and Sri Lanka. PLoS Medicine, 3(6), e195. https://doi.org/10.1371/journal.pmed.0030195

16. Nel, P., \& Righarts, M. (2008). Natural disasters and the risk of violent civil conflict. International Studies Quarterly, 52(1), 159-185. https://doi.org/10.1111/j.1468-2478.2007.00495.x

17. Olshansky, R. B., Hopkins, L. D., \& Johnson, L. A. (2012). Disaster and recovery: Processes compressed in time. Natural Hazards Review, 13(3), 173-178. https://doi.org/10.1061/(ASCE)NH.1527-6996.0000077

18. Parkinson, S., \& Ramirez, R. (2006). Using a sustainable livelihoods approach to assessing the impact of ICTs in development. The Journal of Community Informatics, 2(3).

19. Puspito Sari, D. A., Listiyowati, I., Nefianto, T., \& Lasmono. (2018). The Discrepancy between the Programs and Disaster Management Policy in Klapanunggal District, Bogor, West Java. IOP Conference Series: Earth and Environmental Science, 135(1). https://doi.org/10.1088/1755-1315/135/1/012011

20. Republik Indonesia. (2002). Undang-undang republik indonesia nomor 3 tahun 2002 tentang pertahanan negara.

21. Sari, D. A.P., Innaqa, S., \& Safrilah. (2017). Hazard, Vulnerability and Capacity Mapping for Landslides Risk Analysis using Geographic Information System (GIS). IOP Conference Series: Materials Science and Engineering, 209(1). https://doi.org/10.1088/1757-899X/209/1/012106

22. Sari, Deffi Ayu Puspito, Malahayati, M., Nefianto, T., \& Kertawidana, I. (2018). Disaster Early Warning and Information Services Meteorology, Climatology and Geophysics Agency’s Employees Performance Observed from their Motivation and Competency. International Journal of Multi Discipline Science (IJ-MDS), 1(2), 129136. https://doi.org/10.26737/ij-mds.v1i1.430

23. Wati, V. O., Sari, D. A. P., \& Sutisna, S. (2018). Disaster Relief as Indonesia Soft Power Diplomacy Case of Cyclone Pam in Vanuatu. International Journal of Multi Discipline Science (IJ-MDS), 1(1), 58-69. https://doi.org/10.26737/ij-mds.v1i1.421 